\title{
Model of Quality Management Applied in Lean Green Agriculture Methodology: A Research in Perú
}

\author{
Sebastian Manrique ${ }^{1}$, Kevin Sabogal ${ }^{1}$, Fernando Sotelo, $\mathrm{MSc}^{1}$ and Edgar Ramos, $\mathrm{Mg}^{1}$ \\ ${ }^{1}$ Ingeniería Industrial, Universidad Peruana de Ciencias Aplicadas, Perú \\ \{u201311933@upc.edu.pe,u201321967@upc.edu.pe, fernando.sotelo@upc.edu.pe,pcineram@upc.edu.pe
}

\begin{abstract}
The competition for the development of the agricultural sector worldwide is changing very rapidly. Having sustainable business practices should be the basis of small businesses around the world, as they improve profitability. In this transformation, the agricultural sector is increasingly concerned with strategy, innovation and competition in the effort to be more productive and profitable. This case study will describe the implementation of the Lean Agriculture model in a group of farmers in the district of Mala, Cañete. In addition, it explains how the visits to the farms were carried out, the workshops carried out and the advice so that the farmers understand the benefits of quality in the product that can be achieved through the adoption of this philosophy. Then a new model of strategic skills will be presented to guide small agricultural companies in the sector to achieve success with sustainable results. Finally, it is explained that through the adoption of this model for the transition to become sustainable organizations.
\end{abstract}

Keywords - Lean, Green, Agriculture, Quality Management, Organic Apple

\section{INTRODUCTION}

The lean methodology is one of the most important in the industry in the modern era, because thanks to it, processes can be significantly improved. At present, companies seek to be increasingly competitive and to achieve this they have to find the right way to improve their performance without creating a significant increase in costs. Therefore, many of these companies choose to implement methodologies that help systematically improve all processes.

The lean methodology is known for improving the efficiency of processes in various sectors of the industry and in the same way this methodology helps to reduce costs.

The lean green methodology focuses on the improvement of processes eliminated waste during each of the stages under the basic principles of lean philosophy.

That is, what is sought is to eliminate the actions or activities that do not add value to the final product. Without however, the Green philosophy takes a point of view oriented mainly to the promotion of environment friendly procedures. These will they owe to the growing concern of the industry about the effects caused during the modern era of industrialization.

These effects have deteriorated significantly the health of the planet throughout this time and that is why the process attraction called clean is becoming more and more attractive to investors and clients within the industry.

Digital Object Identifier (DOI):

http://dx.doi.org/10.18687/LACCEI2020.1.1.315

ISBN: 978-958-52071-4-1 ISSN: 2414-6390

\section{LITERATURE REVIEW}

Lean is one of the essential methodologies to ensure that companies or organizations acquire and maintain a competitive advantage. A competitive advantage is achieved when companies maintain practices consistent with sustainable development strategies and, as such, control waste and implement practices that are environmentally and socially responsible [1].

Lena methodology has become one of the most used tools in al kinds of industries. One of the most important reasons for this is that this methodology seeks to eliminate waste and increase the efficiency of resources. That is why, many studies are being carried out within the agricultural sector to be able to attack these problems.

According to [2], lean could contribute to the efficient use of resources and also reduce food waste through the protection of production quality. [3], affirm that reading is a way of specifying value, aligning actions that create value in the best sequence and performing these activities effectively without interruption when requested. That is, do more with less and thus be able to reduce time avoiding tasks that do not increase value.

However, in recent years the concern for the care and maintenance of the environment has increased thus becoming a factor of great importance within the industry. That is why, lean philosophy develops in parallel with the green or green methodology.

On the one hand, according to [4] lean and green practices are synergistic when applied simultaneously. Likewise, according to [4], [5], this means that Lean is beneficial for green practices and practice implementation. This is why the green paradigm has emerged as an operational approach to reduce the negative ecological impact of an organization's products and services, as well as to improve the environmental efficiency of its operations.

On the other hand, according to [6], the lean and green union influences other environmental performance variables, especially waste reduction and waste reduction techniques.

Finally, [7], concluded that lean leads to green and that this promotes the cultural development of the organization that drives the formulation and achievement of green objectives such as waste disposal and pollution prevention.

On the other hand, these methodologies should be applied to sectors where they contribute significantly to the development, not only of the same industry but also of the country. According to [8], estimates between countries, the effect of agricultural GDP growth on poverty reduction is at 
least twice the effect of GDP growth from other sectors. Because the agriculture sector is one of the most important in the world, it is very important to find ways to improve production processes within this sector.

This is how [9], conducted a study about the integration and monitoring of the lean methodology in the coffee sector in Colombia and within the results they found that five of the six properties analyzed process standardization through documentation of the information and the measurement of the indicators that this study considers essential to determine the maturity of the fruit.

In the same way [10], also concluded that lean can offer an opportunity for British farmers to increase their level of competitiveness by reducing waste and improving the quality of food supply.

According to [11], adjusting the size of the production batches is one of the means that the main professionals in the industry have in order to reduce the level of inventory or, in the absence of excess stock. With this, professionals seek to take into consideration the environmental impacts of the production system they handle, thus reducing environmental effects and from a sustainability point of view, reducing carbon emissions and other pollutants.

On the other hand, [12], indicates that in China the green energy revolution that preserves environmental conditions is booming. Considering the ecological, clean and efficient requirements of innovation projects. Considering the implementation process, the effect, the benefit, the environment, the social benefit, the sustainability, a hierarchical evaluation index system was established after the evaluation of the innovation projects.

Ref. [13], propose a model to be more productive, more profitable and sustainable. In this transformation, the agricultural sector is increasingly concerned with strategy, innovation and competition in the effort to be more productive and profitable. Similarly, the sector faces demand to be more responsible with the environment in its policies and practices.

In Ref. [14] provided in one of their most recent studies, an overview of the relative risk of a group of contaminants $(\mathrm{Br}$, $\mathrm{As}, \mathrm{Cd}$ and $\mathrm{Pb}$ ) resulting from the consumption of food groups that come from lean meat of animals. However, the current study allows us to compare between the relative risk of the food groups studied and the scenarios, and other studies that cover the entire diet and that follow long-term dietary patterns are necessary for the absolute risk assessment.

This case study finally concludes that applying the Lean philosophy in conjunction with Green Farming would reduce the effects as emissions would be considered when designing the process. According to [15], the demand for food will double over the next 50 years, so it is essential to consider waste reduction, as well as care of matter and energy.

According to [16], Lean Farming allows not only to reduce waste but also to reduce emissions to the environment. The development of philosophy efficiently is reinforced when the application of green manufacturing and lean manufacturing occur simultaneously.
According to [17], the relationship between green, lean innovation practices and performance in the supply chain. This document presents an innovative approach, since it simultaneously studies the three dimensions of sustainability (environmental, social and economic), the innovation process and green quality procedures, which are considered strategic for the competitiveness of the supply chain.

In [18], notes that the architecture, engineering and construction industry are classified as large consumers of natural resources. Therefore, most construction companies resort to green building designs and acquire different environmental certifications that show that emissions to the environment have been reduced. On the other hand, the lean green management concept is applied to the evaluation of these construction projects in a case study by [19].

On the other hand, [20], points out that the various operations management studies show the good results obtained from the adoption of lean, Green and social management systems. However, despite the importance of these they do not remain constant. Therefore, it is proposed that the system be sustainable and maintained over time. In this way, demonstrating that in order to obtain even better results, organizations must focus on the long-term application of philosophy.

This idea is reinforced by [21], who claim that the sustainability of the application of these good practices guarantees that a model of Lean green philosophy can be maintained over time. In this way, achieving successful results against the environmental impact generated by organizations.

\section{METHODOLOGY}

For this research, a group of farmers from the town of Mala, Cañete province of Lima will be used as a sample where the main crop is the organic apple also called Manzana Delicia. This is the product with the highest volume in that locality.

There will be the participation of 28 farming families all destined for the production of the same type of apple under the same conditions. Table 1, exhibits the current quality problems with the apple production.

TABLE I

PRINCIPAL QUALITY ISSUES

\begin{tabular}{|c|l|}
\hline Priority & \multicolumn{1}{|c|}{ Quality issue } \\
\hline 1 & Overproduction \\
\hline 2 & Error in assigned parcel \\
\hline 3 & $\%$ of defective products \\
\hline 4 & Wheater \\
\hline 5 & Apple with color not uniform \\
\hline 6 & Apples infected by Cydla \\
\hline
\end{tabular}

This group of farmers seeks to improve the quality of the product to be able to enter new markets and take advantage of the production together of all creating relationships with buyers and customers to continue developing in this sector. 


\section{A. Human Resource Training and Awareness}

Training is key to instructing farmers who are part of the production of Apples in Cañete. To do this, as [19] indicates, collective commitments must be established in order to be introduced in conjunction with the adoption of the Lean Green Farming philosophy. Ref. [19] also indicates that the adoption of philosophy as a whole allows for better results than making the adoption individually. The training will be in charge of laying the foundations of the Lean Green philosophy. Herefore, according to [22] it should be adequately detailed how it works and how it will achieve the long-term objectives. For this, a training schedule will be delivered that will provide adequate information for farmers. Each of these meetings will discuss a specific point in philosophy.

\section{B. Procedure design}

According to [13] the design of the procedures should be aimed at achieving the objectives of the Lean Green philosophy model. That is, it must be sustainable by reducing the impact on the environment by eliminating waste and thus maintaining a clean production.

Current modes of agricultural production carry a significant environmental and social burden that cannot be maintained indefinitely and, if you want the global agri-food system to have any hope of keeping up with the growing demand for food, the means of agricultural production, for need, will have to be more sustainable [2].

In addition, being profitable is one of the main effects of this model, so that the optimal design of the procedures would result in an improvement in profitability in the sector. Which is a goal that is constantly sought. The Figure 1 shows the proposed procedure.

According to [24], it is essential that companies must systematically adapt lean principles in order to identify waste, proactive planning and identification of new problems and solve them.

Likewise [10], affirm that the focus of Lean methods is in the evaluation of the added value of a task or entry. They also argue that a continuous focus on achieving product quality is the true measure of an effective farming process and not just efficiency or performance. Therefore, Lean is both a method to analyse the efficiency of the process and the effectiveness of the process in the delivery of products.

\section{Monitoring and control}

The monitoring and control of operations is the most important process in agricultural production because the care and maintenance of products is key to obtaining a quality standard and being able to sell the product without difficulty.

According to [25] Within the lean philosophy, the third Value Stream principle is the technique that consists of mapping all the design, physical production and information actions involved in the production and delivery of the identified product values. Identify any activity that you add without value to remove. Ideally, it should involve a complete value chain in order to have a panoramic view of the situation it is in.

To do this, you must have a basic control record during

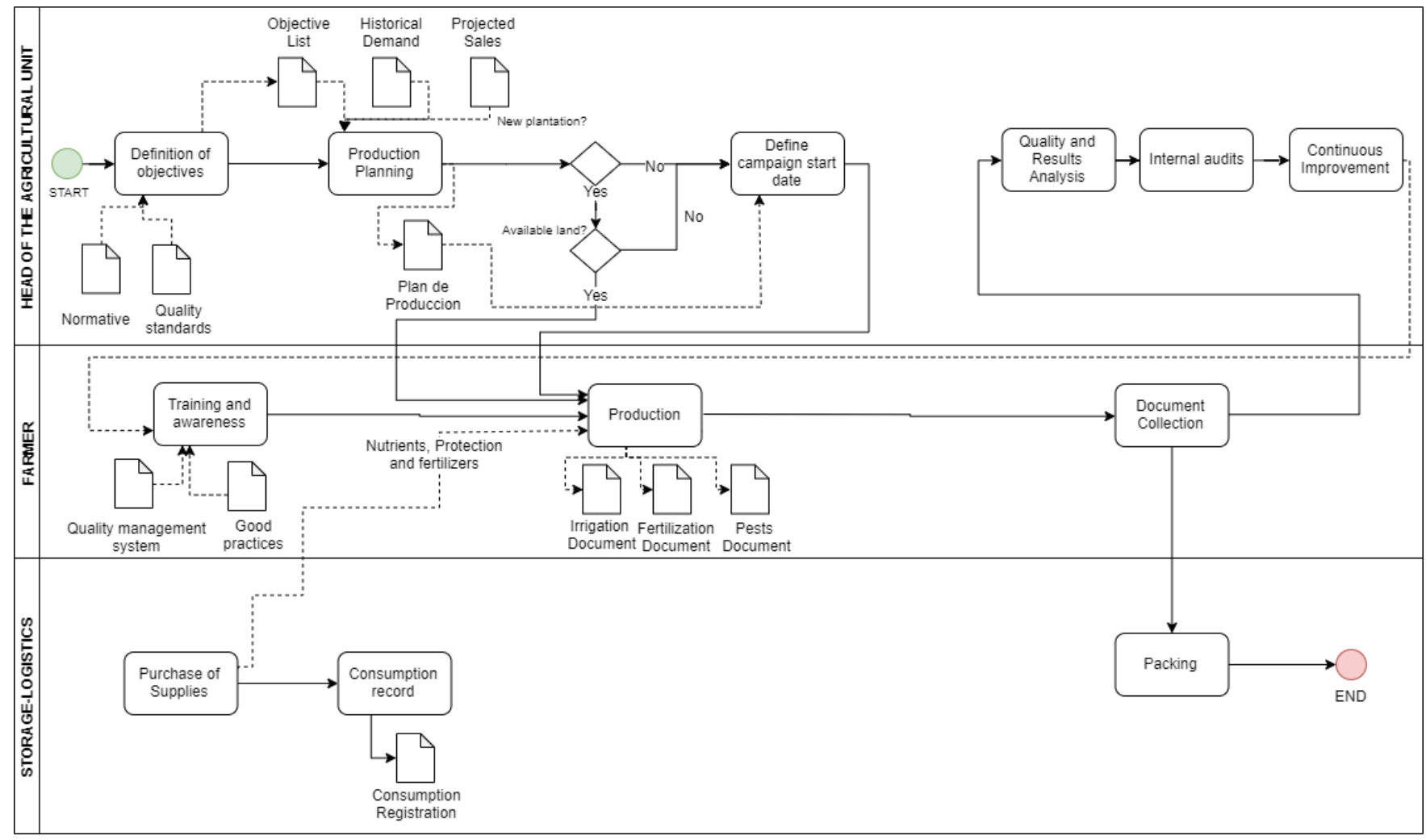

Fig. 1 Proposed procedure

$18^{\text {th }}$ LACCEI International Multi-Conference for Engineering, Education, and Technology: "Engineering, Integration, and Alliances for a Sustainable Development" "Hemispheric Cooperation for Competitiveness and Prosperity on a Knowledge-Based Economy", 29-31 July 2020, Buenos Aires, Argentina. 
the entire production process. This means from the planting of new trees to the harvest of the fruit.

These records will help to implement a culture of traceability, where there is true documentation of all the activities, conditions, situations and processes through which the product has passed since the beginning of a production campaign.

According to [26], the adoption of the Lean production system is a mechanism for improving organizational performance and it is necessary for the leaders of the organizations to promote and disseminate the philosophy in order to adopt it throughout the organization.

According to [10] this allows the farmer to calculate the appropriate information about the total processing time and the cycle time for the crop or herd and, more importantly, the separation and allocation of fixed resources and labour for each agricultural activity.

Once the relevant information about the campaign has been collected, each of the processes must be analysed and the seven changes determined by the lean philosophy (derived from the Toyota production system) must be considered in order to eliminate activities or procedures that do not add value to the final product.

TABLE II

SEVEN CHANGE BY LEAN PHILOSOPHY

\begin{tabular}{|l|l|}
\hline \multicolumn{1}{|c}{ Change } & \multicolumn{1}{|c|}{ Description } \\
\hline Overproduction & $\begin{array}{l}\text { Production for which there are no } \\
\text { orders, waste of resources and employee } \\
\text { time. }\end{array}$ \\
\hline Wait & $\begin{array}{l}\text { The employee's downtime due to delays, } \\
\text { lack of equipment, lack of raw materials. }\end{array}$ \\
\hline Unnecessary transport: & $\begin{array}{l}\text { Transport long distances with inefficient } \\
\text { cargo. }\end{array}$ \\
\hline $\begin{array}{l}\text { Over process or inproper } \\
\text { process }\end{array}$ & $\begin{array}{l}\text { Taking unnecessary steps to process, } \\
\text { non-efficient processing causing } \\
\text { unnecessary movement and causing } \\
\text { defects. }\end{array}$ \\
\hline Excess inventory & $\begin{array}{l}\text { Excess raw material, tools, stagnant } \\
\text { finished products that increase the } \\
\text { number of obsolete or damaged product. }\end{array}$ \\
\hline Unnecessary movement & $\begin{array}{l}\text { Movements that are not for the benefit } \\
\text { of production such as collection of tools } \\
\text { from different points. }\end{array}$ \\
\hline Defective & $\begin{array}{l}\text { Defective production must be eliminated } \\
\text { since it is detected. }\end{array}$ \\
\hline
\end{tabular}

The necessary adjustments must be made within each one of the processes from the plantation to the harvest of the fruit with suitable conditions, in this way, the unnecessary actions and activities that do not generate a value added to the production system can be eliminated.

\section{RESULTS}

Sector revenues are expected to increase by $20 \%$ as the percentage of apples suitable for export would increase which would multiply when a greater number of tons are sold to export and not to meet national market.
Reaching a unit sale price of $0.083 \mathrm{US} / \mathrm{kg}$. reflecting a considerable increase compared to $0.059 \mathrm{US} / \mathrm{kg}$. that is the sale price that is currently handled.

Also, it was found that the training provided by Quality got $87 \%$ attendance. The proposal He pointed out that more than $90 \%$ of assistance should be obtained.

However, this lower percentage is due to the fact that reasons of disinterest in several family units obtained that despite obtaining a smaller percentage the members attending training obtained good results in their evaluations. It was found that the results of the training were optimal obtaining more than $95 \%$ of those evaluated obtained passing grades. The proposal He pointed out that the expected scenario was the one at least $20 \%$ disapproved which would have to go through a training reinforcement to be evaluated again.

The proposal initially contemplated as an impact environmental promotion of good agricultural practices and the promotion of balanced use of resources. Both of them impacts focused on the use of manuals and the application of good practices.

However, it was found that the environmental impact of the project was much greater than which indicated the model initially raised as the development of organic producers implies the reduction in chemicals of up to $90 \%$ in its use. Is reduction in its use derives in a lower emission of gases of greenhouse effect and at the same time the heating effect these days, the weather is a key factor for campaign programming the anomalies in it derived from heating they could dismiss all the proposed programming.

\section{CONCLUSIONS}

This case study focuses solely on assessing the impact generated by quality management on farmers engaged in organic fruit production (apples). As detailed in the present investigation, several authors have emphasized the positive impact generated by the quality management on the crops and the financial performance obtained by the application of good practices. These authors indicated that when an organization develops good quality management practices effectively, its performance will greatly improve from several aspects.

In the literature review it was concluded that there is a direct positive relationship between quality and organizational performance, especially in associativity. However, the main conclusion is based on the fact that customer satisfaction and the quality of the final product can be improved by implementing different quality initiatives in organizations.

Although this research focuses directly on distinguishing the relationship between quality management and organizational performance of farmers, several factors that directly impact organizational performance, such as family unit size, culture and level, were neglected. Training.

Therefore, future research could study the impact of quality management on the performance of farmers with a larger scope when investigating the influences of the abovementioned factors on performance. 


\section{REFERENCES}

[1] I. Alhuraish, C. Robledo y A. Kobi, «A comparative exploration of lean manufacturing and six sigma in terms of their critical success factors,» Journal of Cleaner Production, vol. 164, pp. 325-337, 15102017.

[2] Chávez, J., Osorio, F., Altamirano, E., Raymundo, C., Dominguez, F., "Lean production management model for SME waste reduction in the processed food sector in Peru", Advances in Intelligent Systems and Computing, 971, pp. 53-62.

[3] L. B. M. Costa, M. Godinho Filho, L. D. Fredendall y F. J. Gómez Paredes, «Lean, six sigma and lean six sigma in the food industry: A systematic literature review,» Trends in Food Science \& Technology, vol. 82, pp. 122-133, 1122018.

[4] A. Cherrafi, J. A. Garza-Reyes, V. Kumar, N. Mishra, A. Ghobadian y S. Elfezazi, «Lean, green practices and process innovation: A model for green supply chain performance,» International Journal of Production Economics, vol. 206, pp. 79-92, 1122018.

[5] A. Fercoq, S. Lamouri y V. Carbone, «Lean/Green integration focused on waste reduction techniques,» Journal of Cleaner Production, vol. 137, pp. 567-578, 20112016.

[6] A. Marco-Ferreira, N. O. Stefanelli, B. M. R. P. Seles y R. Fidelis, «Lean and Green: practices, paradigms and future prospects,» Benchmarking: An International Journal, Vols. \%1 de \%2ahead-of-print, $\mathrm{n}^{\mathrm{o}}$ ahead-of-print, 2852019.

[7] M. Dieste, R. Panizzolo, J. A. Garza-Reyes y A. Anosike, «The relationship between lean and environmental performance: Practices and measures,» Journal of Cleaner Production, vol. 224, pp. 120-131, 17 2019.

[8] S. Fallah-Alipour, H. M. Boshrabadi, M. R. Z. Mehrjerdi y D. Hayati, «A Framework for Empirical Assessment of Agricultural Sustainability: The Case of Iran,» Sustainability, vol. 10, nº 12, p. 4823, 17122018.

[9] L. V. Reis, L. M. Kipper, F. D. Giraldo Velásquez, N. Hofmann, R. Frozza, S. A. Ocampo y C. A. Taborda Hernandez, «A model for Lean and Green integration and monitoring for the coffee sector,» Computers and Electronics in Agriculture, vol. 150, pp. 62-73, 172018.

[10]C. Colgan, G. Adam y F. Topolansky, «Why try Lean? A Northumbrian Farm case study,» International Journal of Agricultural Management, vol. $2, \mathrm{n}^{\circ} 3$, p. 170, 2013

[11]M. Tayyab, B. Sarkar y M. Ullah, «Sustainable Lot Size in a Multistage Lean-Green Manufacturing Process under Uncertainty,» Mathematics, vol. 7, nº 1, p. 20, 25122018.

[12]J. Xing, J. Wang, X. Ye, S. Dong y C. He, «Post-evaluation Method and Index System for Energy Internet Projects Based on Attribute Theory,» de 2018 2nd IEEE Conference on Energy Internet and Energy System Integration (EI2), 2018.

[13]H. Barth y M. Melin, «A Green Lean approach to global competition and climate change in the agricultural sector - A Swedish case study,» Journal of Cleaner Production, vol. 204, pp. 183-192, 10122018.

[14]M. Ventura, C. Cardoso, N. M. Bandarra, I. Delgado, I. Coelho, S. Gueifão, M. Ribeiro, M. H. Costa y I. Castanheira, «Bromine, arsenic, cadmium, and lead in several key food groups: an assessment of relative risk,» International Journal of Environmental Analytical Chemistry, vol. 98, nº 15, pp. 1398-1412, 8122018

[15]D. Powell, S. Lundeby, L. Chabada y H. Dreyer, «Lean Six Sigma and environmental sustainability: the case of a Norwegian dairy producer,» International Journal of Lean Six Sigma, vol. 8, nº 1, pp. 53-64, 632017.

[16]Z. F. Ikatrinasari, S. Hasibuan y K. Kosasih, «The Implementation Lean and Green Manufacturing through Sustainable Value Stream Mapping,» IOP Conference Series: Materials Science and Engineering, vol. $453, \mathrm{n}^{\circ}$ 1, p. 012004, 29112018

[17]S. K. Jakhar, H. Rathore y S. K. Mangla, «Is lean synergistic with sustainable supply chain? An empirical investigation from emerging economy,» Resources, Conservation and Recycling, vol. 139, pp. 262269, 1122018.

[18]L. M. Khodeir y R. Othman, «Examining the interaction between lean and sustainability principles in the management process of AEC industry,» Ain Shams Engineering Journal, vol. 9, n 4, pp. 1627-1634, 1122018.

[19]S. Hardikar, R. Wallroth, A. Villringer y K. Ohla, «Shorter-lived neural taste representations in obese compared to lean individuals,» Scientific Reports, vol. 8, $\mathrm{n}^{\circ} 1$, p. 11027, 23122018.
[20]L. Wu, N. Subramanian, A. Gunasekaran, M. D.-A. Abdulrahman, K. S. Pawar y D. Doran, «A two-dimensional, two-level framework for achieving corporate sustainable development: Assessing the return on sustainability initiatives,» Business Strategy and the Environment, vol. 27, $\mathrm{n}^{\circ}$ 8, pp. 1117-1130, 1122018.

[21]L. McAllan, K. R. Maynard, A. S. Kardian, A. S. Stayton, S. L. Fox, E. J. Stephenson, C. E. Kinney, N. K. Alshibli, C. K. Gomes, J. F. Pierre, M. A. Puchowicz, D. Bridges, K. Martinowich y J. C. Han, «Disruption of brain-derived neurotrophic factor production from individual promoters generates distinct body composition phenotypes in mice,» American Journal of Physiology-Endocrinology and Metabolism, vol. 315, $\mathrm{n}^{\circ}$ 6, pp. E1168-E1184, 1122018.

[22]M. Bown, P. Muir y B. Thomson, «Dairy and beef breed effects on beef yield, beef quality and profitability: a review,» New Zealand Journal of Agricultural Research, vol. 59, nº 2, pp. 174-184, 242016.

[23]T. Jemaa, J. Huguenin, C.-H. Moulin y T. Najar, «Les systèmes d'élevage de petits ruminants en Tunisie Centrale: stratégies différenciées et adaptations aux transformations du territoire,» Cahiers Agricultures, vol. 25, no 4, p. 45005, 772016.

[24]E. Psomas, J. Antony y N. Bouranta, «Assessing Lean adoption in food SMEs: Evidence from Greece,» International Journal of Quality \& Reliability Management, vol. 35, nº 1, pp. 64-81, 212018.

[25]E. Cherubini, G. M. Zanghelini, J. M. R. Tavares, F. Belettini y S. R. Soares, «The finishing stage in swine production: influences of feed composition on carbon footprint,» Environment, Development and Sustainability, vol. 17, $\mathrm{n}^{\circ}$ 6, pp. 1313-1328, 30122015.

[26]E. G. Satolo, L. E. d. S. Hiraga, G. A. Goes y W. L. Lourenzani, «Lean production in agribusiness organizations: multiple case studies in a developing country,» International Journal of Lean Six Sigma, vol. 8, $\mathrm{n}^{\circ}$ 3, pp. 335-358, 782017. 